\title{
ВИЯВЛЕННЯ І КОРЕКЦІЯ СИСТЕМНИХ РИЗИКІВ ПРИ РЕАБІЛІТАЦІЇ ХВОРИХ В УМОВАХ САНАТОРІЮ. ПОСТАНОВКА ПРОБЛЕМИ
}

О. В. Сарканич

ТОВ «Сузір'я»

\begin{abstract}
Аналізується методологія оцінювання стану пацієнтів у загальній системі надання медичної допомоги. Обґрунтовується метод оцінки тяжкості стану пацієнту, що базується на принципах персоналізованої медицини.

Оцінка якості перебування пацієнта в санаторії розглядається як макрокритеріальна модель системи надання медичної допомоги, що складається з двох кластерів - відновлення здоров'я в санаторії і отримання повноцінного відпочинку.
\end{abstract}

Ключові слова: оцінка стану пацієнта, системи управління якістю надання медичної допомоги, персоналізована медицина, критерії систем управління якістю, ризик-менеджмент.

\section{THE SYSTEMIC RISKS IDENTIFICATION AND CORRECTION IN THE PATIENT'S SANATORIUM REHABILITATION. FORMULATION OF THE PROBLEM}

\author{
"Suzir'ya» Ltd
}

O. V. Sarkanych

The methodology of assessing patients' condition in the general system of providing medical care is analyzed. A method for assessing the severity of a patient's condition based on the principles of personalized medicine is substantiated.

The evaluation of the patient's stay in the sanatorium is considered as a macro-clinical model of the medical care system, consisting of two clusters - restoring health in a sanatorium and getting a proper rest.

Key words: assessment of the patient's quality management system of medical care, personalized medicine, criteria of quality management systems, risk management.

\section{ВЫЯВЛЕНИЕ И КОРРЕКЦИЯ СИСТЕМНЫХ РИСКОВ ПРИ РЕАБИЛИТАЦИИ БОЛЬНЫХ В УСЛОВИЯХ САНАТОРИЯ. ПОСТАНОВКА ПРОБЛЕМЫ}

А. В. Сарканич

000 «Сузирья»

\begin{abstract}
Анализируется методология оценки состояния пациентов в общей системе оказания медицинской помощи. Обосновывается метод оценки тяжести состояния пациента, основанный на принципах персонализированной медицины.

Оценка качества пребывания пациента в санатории рассматривается как макрокритериальная модель системы оказания медицинской помощи, состоящая из двух кластеров - восстановления здоровья в санатории и получения полноценного отдыха.
\end{abstract}

Ключевые слова: оценка состояния пациента, системы управления качеством оказания медицинской помощи, персонализированная медицина, критерии систем управления качеством, риск-менеджмент.

(C) О. В. Сарканич 
Вступ. Сучасність характеризується вкрай швидкими темпами змін у медицині. За останні роки з'явилися нові, проривні результати досліджень. Фактично, світ знаходиться на межі переходу від стандартизованої до персоналізованої медицини. З'явилися можливості швидкого повного секвенування генома людини. Цей метод надає персональну генетичну інформацію, необхідну для ефективної діагностики та цілеспрямованого лікування захворювань. Уже зараз можна за краплею крові визначити схильність людини до різних захворювань. У розпорядженні медиків з'явилися такі технології, що дозволяють виділити індивідуальні особливості кожного пацієнта, реальним стає генетичний прогноз ризиків як на рівні цілого етносу, так і на рівні сім'ї і конкретного індивіда. Отже, персоналізація в медицині - це не просто врахування особливостей організму, а інтеграція особливостей, що відображені в індивідуальному генетичному коді $[2,7,8]$.

Стосовно реабілітації хворих, і зокрема санаторного етапу, слід підкреслити, що одна 3 головних задач санаторно-курортного лікування полягає в продовженні життя людини за рахунок інволютивного періоду (періоду старіння). Іншими словами, слід враховувати, що основний шлях медицини полягає в супроводі людини 3 моменту 1ii народження протягом життя, корегуючи стиль iii життя і мінімізуючи фактори ризику. Відповідно, головною умовою санаторного етапу ведення пацієнта є максимально можливий облік факторів ризику та індивідуальних особливостей людини.

У санаторному процесі уточнення діагностики і лікування пацієнта етапи індивідуалізації діагностики та лікування пацієнтів, здавалося б, $\epsilon$ мінімальними.

Принцип індивідуалізації добре відомий: існують однакові хвороби, але немає однакових хворих. Практично в усіх посібниках з санаторно-курортного лікування та реабілітації хворих обов'язково вказується, що головною особливістю реабілітаційного етапу лікування хворих є індивідуалізація. Однак, ніякого конкретного сенсу, найчастіше, не вкладається.

Сьогодні важко уникнути стандартизованих підходів, але стосовно до людини ми зможемо визначити найбільш відповідну для неї терапію або ефективний препарат на основі індивідуальної фармакокінетики.

Останніми роками в фізіотерапевтичній практиці стали застосовуватися фізичні фактори низької інтенсивності, так звані інформаційні впливи, які за даними експериментальних і клінічних досліджень впливають не тільки на енергетику, але й на хронобіологічні процеси структур і систем біооб'єкту, оптимізуючи їхні фізіологічні процеси. У цьому плані цікаво застосування структурнорезонансної терапії, заснованої на використанні електромагнітного випромінювання і електричного струму в певному частотному ритмі функціонування живої матерії, що сприяє оптимізації діяльності біооб'єкту на субклітинному, клітинному, тканинному, органному, системному і організменому рівнях.

Важливим принципом санаторного лікування дітей $є$ індивідуалізація лікарських призначень 3 урахуванням особливостей організму, перебігу хвороби, попередньої терапії, щоб доцільно поєднувати бальнеотерапію, фізіотерапію, лікувальну фізкультуру, масаж, ортопедичне та інші види спеціального лікування, уникнути поліпрагмазії, енергетичного перенавантаження організму.

Важливою залишається розробка технології 3 використанням моніторингу показників, що відповідають принципу персоналізації проведених процедур, і оцінка її ефективності. Подібний підхід знаходить своє широке відображення в літературі. Відомо, що сучасні тенденції розвитку відновлювальної медицини засновані на персоналізації програм застосування нефармацевтичних технологій у процесі медичної реабілітації та профілактики загострень хронічних захворювань. Так, описаний моніторинг поверхневого імпедансу шкіри піделектродного простору, який покладений в основу загальної технології динамічної електронейростимуляціі та забезпечує індивідуалізацію параметрів і локалізації процедур імпульсної електротерапії [1].

Принцип динамічного лікування фізичними факторами, що складається в зміні їхніх параметрів і зон впливу відповідно до змін актуального стану пацієнта, $є$ необхідною умовою ефективності фізіотерапії і становить основу їі персоналізованого застосування [5]. У більшості відомих на даний час апаратів для черезшкірної електронейростімуляціі використовують ручне регулювання параметрів і вибору зон стимуляції, регламентоване відповідними методичними рекомендаціями. При цьому, в зв'язку з великою різноманітністю швидкозмінних індивідуальних реакцій на проведену процедуру, реальної її персоналізації досягти проблематично. Відповідно автором показано, що актуальним є застосування апаратури, яка забезпе- 
чує автоматичну зміну параметрів стимулюючих імпульсів на основі аналізу сигналів у відповідь індивідуальних реакцій. Цей же підхід може служити для виявлення латентних тригерних точок, різні патерни розподілу яких вимагають персоналізованого лікування.

Мета дослідження - обгрунтувати принципи індивідуалізації санаторно-курортного лікування.

Результати дослідження та їх обговорення. Беручи до уваги труднощі істинної персоналізованої медицини, на даному етапі розвитку основою санаторного лікування можна вважати використання такої інформації про стан хворого, яка ідентифікує i визначає як особливості моніторингу його стану, так і принципи обраного лікування. По суті, йдеться про використання методів спрямованого пацієнтоорієнтованого лікувально-діагностичного впливу, на основі врахування впливів генетичних, середовищних та регіональних факторів [9-11].

Після отримання первинної інформації можливо застосування концепції персоніфікованої, або предикативної (попереджувальної) медицини, яка здатна істотно підвищити якість лікування. Одним 3 нових факторів подібної стратегії $є$ виявлення, оцінка, моніторинг та визначення ступеня впливу ризиків погіршення стану [6]. Особливість підходу полягає в тому, що обгрунтування ризиків проводиться на базі вже згаданих характеристичних симптомів, які складаються не з загальної вельми великої кількості всіх показників, а з особливостей динаміки показників, унікальних для кожного пацієнта. Саме такий підхід розглянуто в роботі О. П. Мінцера (2016) [4].

Зазначені показники складаються 3 трьох груп: динаміка показників при адаптації до навантаження; динаміка показників під час стійкого навантаження; i, нарешті, динаміка повернення до вихідного стану після навантаження. Зрозуміло, можливо розглядати і динаміку при фармацевтичному навантаженні або під час лікувальних процедур. В рамках запропонованого підходу ми вважаємо, що аналіз трендів - один з нечисленних варіантів забезпечення ефективності лікування пацієнтів на сьогодні.

Запропоновані методи, засновані на комплексному впливі різних лікувальних факторів, здебільшого орієнтовані на застосування в умовах лікувально-профілактичних і санаторно-курортних установ. У той же час концепція відновної медицини орієнтована на активну участь пацієнтів у здійсненні лікувально-профілактичних і реабілітаційних заходів. Особливе значення ця орієнтація набуває відносно хворих, які страждають на хронічні больові синдроми, що потребують регулярного отримання відповідної допомоги. Тому актуальна розробка методик і апаратури, придатних для самостійного застосування пацієнтами.

Друга особливість розвитку системи охорони здоров'я полягає в тому, що вона стає не медициною лікування хворих людей, а медициною супроводу здорових. Це дуже важлива ідеологічна відмінність, яка повинна бути врахованою в санаторно-курортному етапі реабілітації.

При цьому має бути забезпеченою якість життя як інтегральна характеристика фізичного, психологічного та соціального функціонування здорової чи хворої людини, заснована на її суб'єктивному сприйнятті. Необхідно враховувати не тільки фактори, пов'язані з самим захворюванням, але й фактори, що відображають якість життя.

Однак дотепер не розроблено коректні методики оцінки динаміки факторів ризику в часі, придатні для клінічної практики, окрім вже згаданої великої кількості факторів ризику, що становлять сотні, навіть якщо враховувати тільки широко відомі дослідження.

Вважаємо, що настав час для серйозного аналізу факторів ризику, визначення напрямків ризик-менеджменту як складової частини стратегії реабілітації. Він повинен являти собою процес підготовки і реалізації медичних заходів, мета яких - зниження небезпеки прийняття помилкових рішень і зменшення негативних наслідків небажаного розвитку подій під час реалізації прийнятих лікарем рішень. Необхідно підкреслити, що ризик-менеджмент з'єднує науку і мистецтво управління ризиком, засновані на довгостроковому індивідуальному прогнозуванні, стратегічному плануванні, виробленні обгрунтованої концепції і програм, адаптованих до невизначеності, що дозволяє не допускати або зменшувати можливі несприятливі впливи різних чинників [3, 6].

Отже, персоніфікована (персоналізована) медицина повинна розглядатися як стратегія профілактики, діагностики та лікування хвороб конкретної людини на основі даних про молекулярно-генетичні особливості структур їі організму. Повною мірою, природно, що концепція персоналізованої медицини є актуальною і щодо медичної реабілітації пацієнтів з поширеними захворюваннями.

Можна констатувати, що підходи до персоналізованої діагностики та лікування захворювань 
більшою мірою, а іноді і виключно, пов'язані з або пошуком так званих біомаркерів, тобто структурних утворень на молекулярно-генетичному рівні, асоційованих із захворюваннями або ризиками їх розвитку, або з вторинними відображеннями змін в органах і системах. Важливо, щоб при цьому 3 поля зору дослідників і практикуючих лікарів не випадали інші чинники та умови, пов'язані як 3 ризиком розвитку захворювань, так і їхніми безпосередніми причинами і проявами. Закладений в медичні технології індивідуальний функціональний підхід до призначення реабілітаційних процедур повинен враховувати прогнозні критерії та предиктори їхної ефективності.

Тільки в цьому випадку можна забезпечити ефективність і вибірковість технологій лікування та реабілітації.

Висновки.

1. Запропоновано загальну концептуальну модель забезпечення системи якості реабілітації в санаторії на принципах персоналізованої медицини.

2. Оцінка яко сті перебування пацієнта в санаторії розглядається як макрокритеріальна модель системи надання медичної допомоги, що складається 3 двох кластерів - відновлення здоров'я в санаторії та отримання повноцінного відпочинку.

\section{Література.}

1. Бобровницкий И. П. Функциональный подход в персонализации программ медицинской реабилитации больных распространенными соматическими заболеваниями / И. П. Бобровницкий // Материалы международного конгресса «Реабилитация и санаторно-курортное лечение 2012» (Москва, 24-25 сентября 2012 г.). - М., 2012. - С . 11-12.

2. Кравченко И. Э. Персонализация лечения больных стрептококковыми ангинами на основе определения активности метаболических ферментных систем / И. Э. Кравченко, Н. И. Брико, В. Х. Фазылов // Эпидемиология и инфекционные болезни. - 2011. — № 4. - С. 4-7.

3. Лифшиц А. С. Управленческие решения : учеб. пособие / А. С. Лифшиц. - Москва : КНОРУС, 2009. $-248 \mathrm{c}$.

4. Мінцер О. П. Реальні горизонти персоналізованої медицини. Стратегія й варіанти розвитку / О. П. Мінцер, В. В. Вішневський. - Медична інформатика та інженерія. - 2016. - № 4. - С. 7-11.

5. Пономаренко Г. Н. Физические методы лечения : справочник / Г. Н Пономаренко. - 3-е изд., перераб. И доп. - СПб : ИИЦ ВМА, 2006. - 336 с.
6. Риск-менеджмент инвестиционного проекта : учебник І под общ. ред. М. В. Грачевой, А. Б. Секерина. Москва : ЮНИТИ-ДАНА, 2009. - 544 с.

7. Рявкин С. Ю. Дилемма стандартизации и персонификации рефлексотерапии: поиски компромисса на примере динамической электронейростимуляции I С. Ю. Рявкин, А. М. Василенко ІІ Тезисы докладов VI всероссийской конференции рефлексотерапевтов. — М., 2012. - С. б4-б8.

8. Рявкин С. Ю. Персонализация применения импульсной электротерапии в лечении больных с поясничными дорсопатиями : автореф. дис. на соискание ученой степени канд. мед. наук : спец. 14.03.11 «Восстановительная медицина, спортивная медицина, лечебная физкультура, курортология и физиотерапия» I С. Ю. Рявкин. - М., 2013 - 23 с.

9. Системи управління якістю. Основні положення та словник термінів (ISO 9000:2005, IDT) : ДСТУ ISO 9000:2007. - [Чинний від 2008-01-01]. — К. : Держспоживстандарт України, 2008. - 29 с. - (Національний стандарт України).

10. Федорков Е. Д. Управление в медицинских и социальных системах на основе моделирования и оптимизации дуальных динамических процессов : автореф. дис. на соискание ученой степени д-ра тех. наук : спец. 05.13.10 «Управление в социальных и экономических системах» I Е. Д. Федорков. - М., 1999. - $42 \mathrm{c}$.

11. Jain K. K. From molecular diagnostics to personalized medicine I K. K. Jain II Expert Rev. Mol. Diagn. 2002. - Vol. 2, No. 4. - P. 299-301.

\section{References.}

1. Bobrovnitskii, I. P. (2012). Funktsional'nyi podkhod $\mathrm{v}$ personalizatsii programm meditsinskoi reabilitatsii bol'nykh rasprostranennymi somaticheskimi zabolevaniyami [Functional approach in personalizing the programs of medical rehabilitation of patients with common somatic diseases]. Materials of the international congress «Rehabilitation and sanatorium-and-spa treatment 2012» (Moscow, 24-25 September 2012). Ministry of Health of the Russian Federation, Moscow [in Russian].

2. Kravchenko, I. E., Briko, N. I., \& Fazylov, V. Kh. (2011). Personalizatsiya lecheniya bol'nykh streptokokkovymi anginami na osnove opredeleniya aktivnosti metabolicheskikh fermentnykh system [Personalization of treatment of patients with streptococcal angina based on the activity of metabolic enzyme systems]. Epidemiologiya i infektsionnye bolezni (Epidemiology and Infectious Diseases), 4, 4-7 [in Russian].

3. Lifshits, A. S. (2009). Upravlencheskie resheniya [Management solutions] textbook. Moscow: KNORUS [in Russian].

4. Mintser, O. P., \& Vyshnevskyy, V. V. (2016). Real'ni gorizonti personaHzovanoi meditsini. Strategiya $i$ 
varianti rozvitku [The real horizons of personalized medicine. Strategy and development options]. Medichna informatika ta inzheneriya (Medical Informatics and Engineering), 4, 7-11 [in Ukrainian].

5. Ponomarenko, G. N. (2006). Fizicheskie metody lecheniya [Physical methods of treatment] handbook. 3th ed. SPb: IITs VMA [in Russian].

6. Grachevoi, M. V., Sekerina, \& A. B. (Eds.) (2009). Risk-menedzhment investitsionnogo proekta [Risk management of the investment project] textbook. Moscow: YuNITI-DANA [in Russian].

7. Ryavkin, S. Yu., \& Vasilenko, A. M. (2012). Dilemma standartizatsii i personifikatsii refleksoterapii: poiski kompromissa na primere dinamicheskoi elektroneirostimulyatsii [The dilemma of standardization and personification of reflexotherapy: the search for a compromise on the example of dynamic electroneurostimulation]. Abstracts of the VI AllRussian Conference of Reflexotherapists (p. 64-68). Moscow [in Russian].

8. Ryavkin, S. Yu. (2013). Personalizatsiya primeneniya impul'snoi elektroterapii $\mathrm{v}$ lechenii bol'nykh $\mathrm{s}$ poyasnichnymi dorsopatiyami [Personalization of the use of pulse electrotherapy in the treatment of patients with lumbar dorsopathy]. (Candidate dissertation). FSBI «Russian scientific center of medical rehabilitation and curative medicine of the Ministry of Health of Russia», Moscow [in Russian].

9. Sistemi upravlinnya yakistyu. Osnovni polozhennya ta slovnik terminiv [Quality management systems. Basic provisions and vocabulary] (ISO 9000:2005, IDT): DSTU ISO 9000:2007. (2008). State Committee for Technical Regulation and Consumer Policy (Derzhspozhivstandart), Kyiv, Ukraine [in Ukrainian]. 10. Fedorkov, E. D. (1999). Upravlenie v meditsinskikh i sotsial'nykh sistemakh na osnove modelirovaniya i optimizatsii dual'nykh dinamicheskikh protsessov [Management in medical and social systems on the basis of modeling and optimization of dual dynamic processes]. (Doctoral dissertation). Voronezh State Technical University, Voronezh [in Russian].

11. Jain, K. K. (2002). From molecular diagnostics to personalized medicine. Expert Rev. Mol. Diagn., 2(4), 299-301. 